\title{
EVALUASI CITRA WORLDVIEW-2 UNTUK PENDUGAAN KEDALAMAN PERAIRAN DANGKAL PULAU KELAPA-HARAPAN MENGGUNAKAN ALGORITMA RASIO BAND
}

\author{
T.Subarno ${ }^{a}$, V.P.Siregar ${ }^{b}$, S.B.Agus ${ }^{c}$ \\ ${ }^{a}$ Program Studi Tekonologi Kelautan_Institut Pertanian Bogor, Indonesia, email: allanawani@gmail.com \\ ${ }^{b}$ Program Studi Tekonologi Kelautan_Institut Pertanian Bogor, Indonesia, email: vingar56@yahoo.com \\ ${ }^{c}$ Program Studi Tekonologi Kelautan_Institut Pertanian Bogor, Indonesia, email: mycacul@gmail.com
}

Article Info;

Received:

30 March 2015

in revised form:

10 April 2015

Accepted:

25 April 2015

Available Online:

30 April 2015

Keywords:

WorldView-2

imagery, water

depth, shallow

water

\section{Info Artikel;}

Diterima:

30 Maret 2015

Hasil Revisi :

10 April 2015

Disetujui:

25 April 2015

Publikasi On-Line:

30 April 2015

\section{Kata kunci:}

Citra WordView-2,

Rasio Band,

Kedalaman, Perairan

Dangkal

\begin{abstract}
Remote sensing technology is so advanced that recently produced satellite sensors with the capability to provide imagery options with very high spatial resolutions. One of the options is WorldView-2 that has 1.84 meter of spatial resolution. Besides, WorldView-2 also has at least five bands on visible rays. The capability of remote sensing for underwater detection through specific depths and the availability of its bands on visible rays give more appropriate options to apply logarithm bands ratio on shallow water depth estimation. This research is aimed at analyzing the capability of WorldView-2 imagery to estimate shallow water depth of Kelapa-Harapan islands by using bands ratio algorithm. There were six bands combination used in applying band 1 through band 4 of WorldView-2 imagery. The results have shown that the best combination of bands to estimate the shallow water depth in the study area is the ratio between band 1 and band 3 with the $R 2$ value of 0.067 and the average bias of $0.66 \mathrm{~m}$. The ratio between band 1 and band 4 gave the value of $R 2$ as big as 0.55 of its regression to the field depth samples. Meanwhile, the other four bands combination ratios have shown very low correlations to the water depth in the field. (C) 2015 GJGP UNDIP. All rights reserved.
\end{abstract}

\begin{abstract}
Abstrak: Perkembangan teknologi penginderaan jauh saat ini telah menghasilkan sensor satelit dengan kemampuan untuk menyediakan pilihan citra satelit dengan resolusi spasial sangat tinggi, diantaranya adalah citra WorldView-2 dengan resolusi spasial 1,84 $\mathrm{m}$. Selain memiliki resolusi spasial sangat tinggi, citra WorldView-2 juga memiliki setidaknya 5 band pada sinar tampak. Kemampuan penginderaan jauh untuk mendeteksi kolom air hingga kedalaman tertentu dan tersedianya pilihan band pada sinar tampak memberikan cukup banyak pilihan untuk mengaplikasikan algoritma rasio band dalam menduga kedalaman suatu perairan. Penelitian ini bermaksud mengkaji kemampuan citra WorldView-2 untuk menduga kedalaman pada perairan pulau Kelapa-Harapan dengan menggunakan algoritma rasio band. Sebanyak 6 kombinasi band digunakan dengan memanfaatkan band 1 sampai band 4 citra WorldView-2. Hasil kajian menunjukkan kombinasi band terbaik untuk menduga kedalaman perairan adalah rasio antara band 1 dan band 3 dengan nilai $R^{2}$ sebesar 0,67 , dan rata-rata bias sebesar 0,66. Rasio antara band 1 dan band 4 memberikan nilai $R^{2}$ sebesar 0,55 dari hasil regresi terhadap sampel kedalaman lapangan. Sedangkan 4 kombinasi rasio band lainnya menunjukkan korelasi yang sangat rendah terhadap kedalaman lapangan. (C) 2015 GJGP UNDIP. All rights reserved.
\end{abstract}

\section{PENDAHULUAN}

Kemampuan cahaya untuk menembus kolom air hingga kedalaman tertentu menjadi keunggulan penginderaan jauh untuk melakukan studi pada kolom hingga dasar perairan dangkal. Perkembangan tekonologi penginderaan jauh saat ini telah menghasilkan banyak jenis sensor satelit dengan kemampuan yang baik untuk mengkaji permukaan air dan mendeteksi kolom air hingga dasar perairan dangkal. Beberapa jenis sensor telah tersedia dengan kemampuan membedakan objek secara spasial (resolusi 
spasial) yang sangat tinggi, diantaranya adalah sensor satelit WordView-2 dengan resolusi spasial 1,85 $\mathrm{m}$ untuk citra multispektral dan 0,5 m untuk pankromatik.

Aplikasi teknologi penginderaan jauh di wilayah pesisir dan laut saat ini merupakan salah satu elemen kunci yang digunakan baik untuk keperluan penelitian maupun pengelolaan sumber daya dan lingkungan (Kay et al. 2009; Kuffner et al. 2007; Friendlanders 2007). Diantara aplikasi penginderaan jauh di wilayah perairan adalah untuk memetakan batimetri suatu perairan dangkal karena kemampuan citra satelit untuk mendeteksi kolom air. Beberapa algoritma telah dikembangkan untuk mengestimasi kedalaman perairan dari citra satelit. Stumpf et al. (2003) adalah salah satunya yang mengembangkan algoritma pendugaan kedalaman perairan dengan memanfaatkan rasio 2 buah band. Pengembangan algoritma menggunakan rasio band tersebut dilakukan karena adanya perbedaan respon spketral kolom air dan dasar perairan terhadap gelombang elektromagnetik (GEM) pada panjang gelombang yang berbeda (Stumpf et al. 2003; Loomis 2009). Jenis dan jumlah material dalam kolom air berperan penting dalam penyerapan dan pemantulan GEM yang mencapai dasar perairan dangkal. Selain itu, jenis substrat pada dasar perairan dangkal juga turut andil dalam proses penyerapan dan pemantulan GEM. Penggunaan rasio band untuk menduga kedalaman diharapkan akan memberikan hasil dugaan kedalaman yang lebih akurat karena sifat perairan yang memberikan respon berbeda terhadap penetrasi gelombang elektromagnetik (GEM) di dalam kolom air.

Sensor satelit memiliki band pada gelombang sinar tampak dengan rentang panjang gelombang yang berbeda-beda. Sensor satelit WorldView-2 memiliki 5 buah band pada rentang panjang gelombang sinar tampak, yaitu band coastal (1), blue (2), green (3), yellow (4), dan red (5). Dari 5 band pada gelombang sinar tampak ini, setidaknya terdapat 10 pasang band yang berpotensi untuk digunakan menduga kedalaman dari citra WorldView-2 menggunakan algoritma rasio 2 buah band. Adanya sifat respon spektral yang berbeda-beda pada masing-masing band sensor satelit pada suatu perairan, memungkinkan untuk mencari kombinasi band terbaik dalam mengestimasi kedalaman dan memetakan batimetri pada perairan Pulau Kelapa dan sekitarnya.

Perairan Kepulau Seribu secara umum memiliki nilai kecerahan 9,5 m (Susilo 2007). Dengan nilai kecerahan ini, berarti bahwa GEM sangat sulit untuk menembus kolom air lebih dalam, terutama pada panjang gelombang merah. Jika band merah tidak digunakan karena keterbatasan tersebut, masih terdapat empat band WorldView-2 (coastal, blue, green, dan yellow) dengan 6 pasangan kombinasi rasio band yang dapat digunakan untuk menduga kedalaman yaitu coastal/blue, coastal/green, coastal/yellow, blue/green, blue/yellow, dan green/yellow. Penelitian ini bermaksud mengkaji potensi dari 4 buah band tersebut dan menentukan pasangan band terbaik untuk menduga kedalaman pada perairan Pulau Kelapa dengan menggunakan algoritma rasio band.

\section{DATA DAN METODE}

Gambar 1. Lokasi kajian pada wilayah perairan pulau Kelapa-harapan (Citra Satelit, 2014)

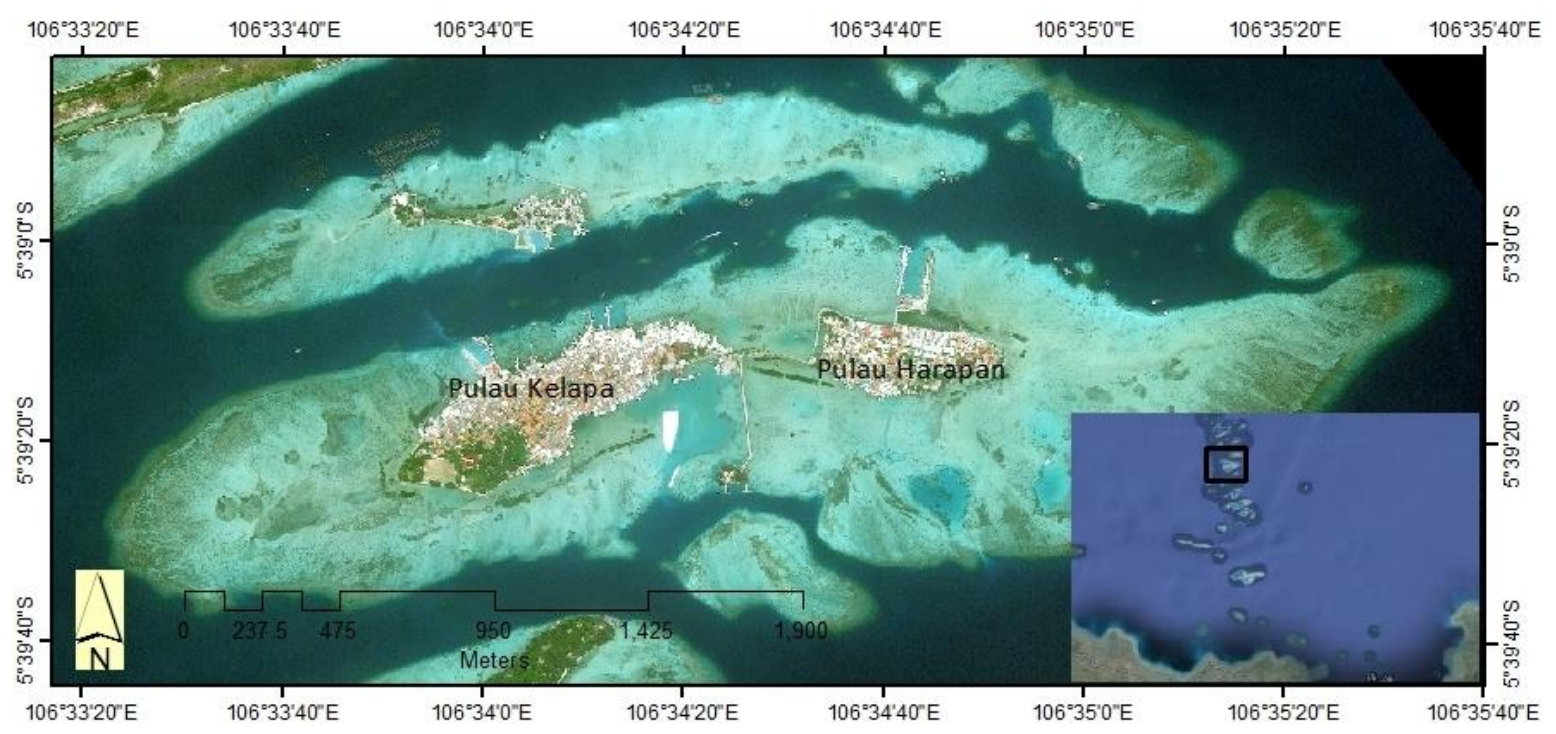


Lokasi kajian yaitu perairan pulau Kelapa dan Harapan, kedua pulau ini masuk dalam kawasan Taman Nasional Laut Kepulauan Seribu dan termasuk dalam wilayah administrasi Kecamatan Kepulauan Seribu Utara, Kabupaten Kepulauan Seribu. Data yang digunakan dalam kajian ini adalah citra WorldView-2, data hasil sounding di lapangan, dan data pasang surut. Citra WorldView-2 yang digunakan diperoleh dari DigitalGlobe dengan akuisisi tanggal 5 Oktober 2013. Sensor WorldView-2 dilengkapi 9 band Pankromatik (632, $2 \mathrm{~nm})$, Multispectral Coastal $(427,3 \mathrm{~nm})$, Blue $(477,9 \mathrm{~nm})$, Green $(546,2 \mathrm{~nm})$, Yellow $(607,8 \mathrm{~nm})$, Red $(658,8 \mathrm{~nm})$, Red Edge $(723,7 \mathrm{~nm})$, dan Inframerah dekat NIR $1(831,3 \mathrm{~nm})$ dan NIR $2(908,0 \mathrm{~nm})$. Data lapangan berupa data sounding yang telah dikoreksi pasang surut dan kemudian digunakan sebagai sampel regresi terhadap hasil rasio band untuk dikalibrasi ke kedalaman aktual yang diestimasi dari citra.

Citra WorldView-2 yang digunakan sebelum dilakukan proses lebih lanjut terlebih dahulu dilakukan masking untuk menutup wilayah daratan dan koreksi radiometrik untuk mengurangi distorsi radiometrik pada citra. Masking dilakukan dengan memanfaatkan band 8 (NIR-2), pemilihan band ini dikarenakan respon spektral antara darat dan laut pada band NIR-2 sangat kontras sehingga cukup baik digunakan untuk membedakan antara darat dan laut. Citra WorldView-2 yang telah dimasking dan dikoreksi radiometrik selanjutnya dikonversi dari informasi nilai digital/digital number (DN) pada setiap piksel menjadi nilai reflektansi. Konversi nilai digital citra menjadi nilai reflektansi dilakukan melalui 2 tahap (Loomis, 2009; Madden, 2011). Tahap pertama yaitu mengkonversi DN menjadi radiansi (Spectral Radiance) dengan persamaan (Digital Globe, 2010) :

$$
\mathrm{L}_{\lambda \text { Pixel }_{,} \text {Band }}=\frac{\mathrm{K}_{\mathrm{Band}} \mathrm{x} \mathrm{q}_{\text {Pixel,Band }}}{\Delta \lambda_{\text {band }}}
$$

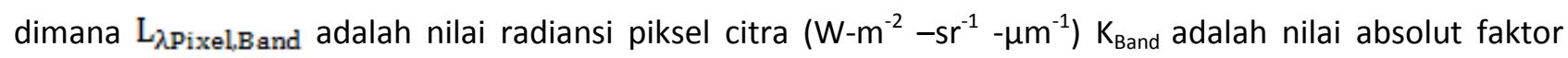
kalibrasi masing-masing band $\left(\mathrm{W}-\mathrm{m}^{-2}-\mathrm{sr}^{-1}\right.$-count $\left.{ }^{-1}\right), \mathrm{q}_{\text {pixel }}$ adalah nilai digital piksel pada masing-masing band, dan $\Delta \lambda_{\text {Band }}$ lebar efektif masing-masing band.

Nilai radiansi selanjutnya dikonversi menjadi nilai reflektansi dengan persamaan (Digital Globe, 2010) :

$$
\rho_{\lambda \text { Pixel }_{x} \text { Band }}=\frac{L_{\lambda \text { Pixel }_{2} \text { Band }} x d_{E S}^{2} x \pi}{E s u n_{\lambda \text { Band }} x \cos \left(\theta_{S}\right)}
$$

dimana $\rho_{\lambda \text { Pixel,Band }}$ adalah nilai rata-rata reflektansi masing-masing band, $\mathrm{L}_{\lambda \text { Pixel,Band }}$ adalah nilai radiansi piksel citra, $d_{\mathrm{ES}}{ }^{2}$ adalah jarak bumi-matahari pada saat perekaman citra, Esun丸Band adalah nilai solar irradiance masing-masing band, dan $\theta$ adalah solar zenith angle.

Selanjutnya dilakukan estimasi kedalaman perairan melalui citra WorldView-2 dengan menggunakan algoritma yang dikembangkan oleh Stumpf et al. (2003), yang ditulis :

$$
\mathrm{Z}=\mathrm{m}_{1} \frac{\left.\ln n R_{\mathrm{W}}\left(\lambda_{i}\right)\right)}{\ln \left(n R_{\mathrm{w}}\left(\lambda_{j}\right)\right)}-m_{0}
$$

dimana $Z$ = kedalaman estimasi, $m_{1}=$ koefisien kalibrasi masing-masing band, $R_{w}(\lambda)=$ nilai reflektansi piksel pada setiap band, $m_{0}=$ faktor koreksi untuk kedalaman 0 , dan $n=$ konstanta untuk menjaga rasio tetap positif. Koefisien $\mathrm{m}_{1}$ dan $\mathrm{m}_{0}$ masing-masing diperoleh dari hasil regresi rasio band terhadap kedalaman lapangan. Dengan demikian untuk memperoleh kedalaman duga dari hasil regresi rasio nilai-nilai reflektansi pada masing-masing band yang digunakan, persamaan (3) dapat ditulis ulang berdasarkan persamaan regresi linear menjadi (Madden 2011):

$$
\mathrm{Y}=\mathrm{aX}+\mathrm{b}
$$

dimana nilai slope (a) mewakili koefisien $\mathrm{m}_{1}$, nilai intercept (b) mewakili koefisien $\mathrm{m}_{0}$, dan nilai $\mathrm{X}$ mewakili hasil rasio nilai reflektansi pada band yang digunakan. 


\section{HASIL DAN PEMBAHASAN}

\subsection{Estimasi Kedalaman}

Sampel data kedalaman lapangan yang digunakan dalam mengestimasi kedalaman perairan wilayah kajian melalui citra WorldView-2 adalah sebanyak 130 titik yang tersebar mewakili setiap tingkat kedalaman. Data lapangan ini diperoleh melalui hasil sounding yang dilakukan pada tanggal 1819 Maret 2015. Data kedalaman lapangan yang digunakan telah dikoreksi pasang surut menggunakan data pasut hasil pengukuran pada stasiun pulau Panggang (wilayah kepulauan seribu bagian selatan). Algoritma rasio band memerlukan masukan nilai-nilai piksel pada setiap band dalam bentuk nilai reflektansi. Setelah pengolahan awal citra, pada kajian ini nilai-nilai digital setiap piksel dikonversi terlebih dahulu menjadi nilai reflektansi mengikuti prosedur dan menggunakan algoritma yang disediakan oleh DigitalGlobe (2010). Perhitungan nilai rasio band dilakukan dengan menjadikan band dengan panjang gelombang lebih pendek sebagai pembilang dan band dengan panjang gelombang lebih panjang sebagai penyebut (Stumpf et al 2003; Loomis 2009). Dari hasil pengujian 6 kombinasi band yang digunakan dalam kajian ini melalui regresi dengan sampel data lapangan, diperoleh hasil yang berbeda-beda (lihat pada Gambar 2).

Gambar 2. Hasil regresi rasio band terhadap sampel kedalaman lapangan, a) Rasio B1/B2; b) Rasio B1/B3; c) Rasio B1/B4; d) Rasio B2/B3; e) Rasio B2/B4; dan f) rasio B3/B4 (Analisis, 2014)
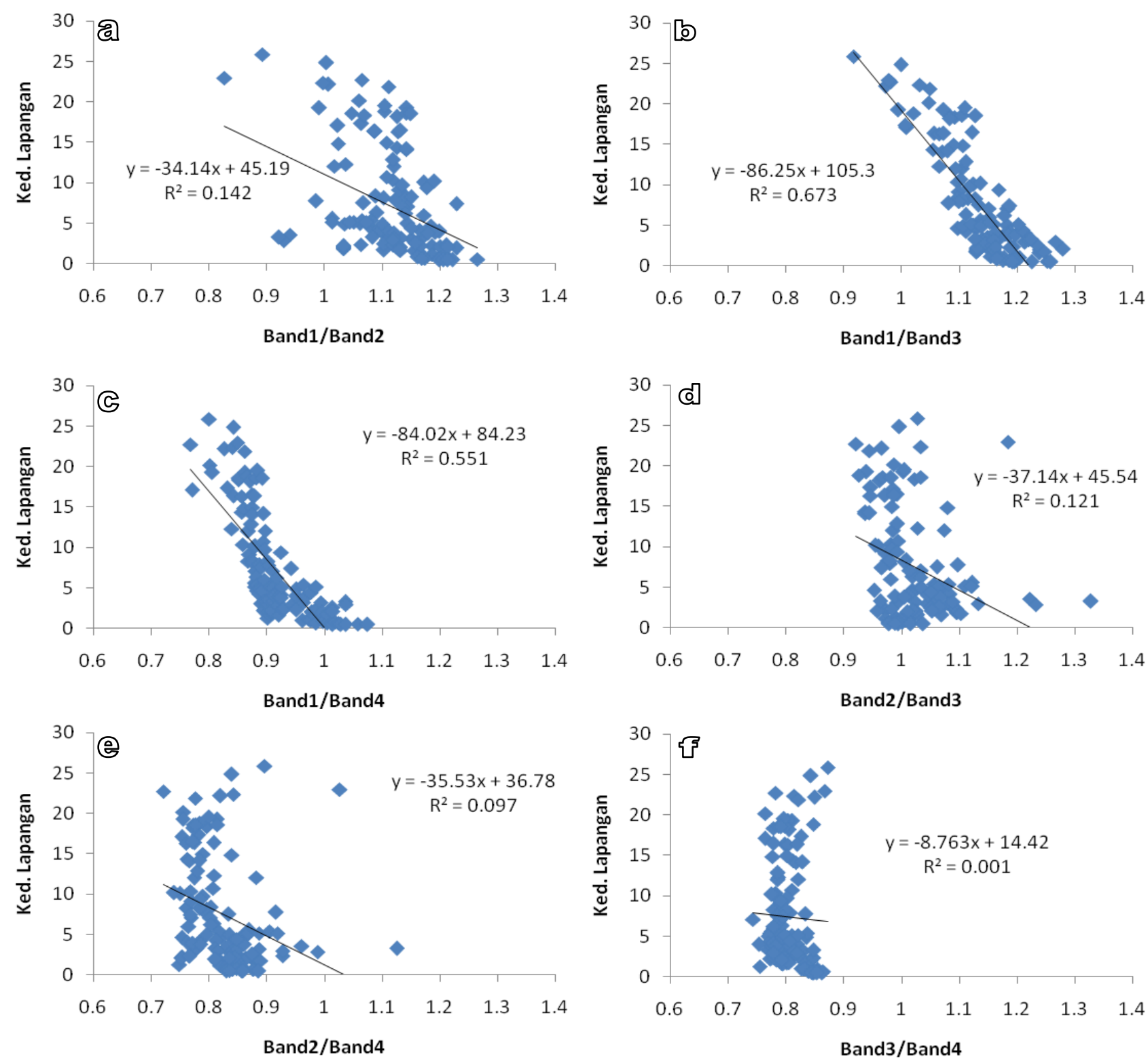
Hasil regresi 6 kombinasi rasio nilai reflektansi band terhadap data kedalaman lapangan terlihat bahwa hanya ada dua kombinasi band yang memiliki korelasi cukup baik dengan sampel kedalaman yang digunakan yakni rasio antara band 1 dengan band 3 (dengan nilai koefisien determinasi $R^{2}=0,67$ ) dan rasio antara band 1 dengan band $4\left(R^{2}=0,55\right)$ sebagaimana terlihat pada Gambar $2 b$ dan $c$. Adapun 4 kombinasi band lainnya memberikan korelasi yang sangat lemah terhadap data lapangan. Hal ini diduga disebabkan oleh sampel data kedalaman lapangan yang diambil kurang mewakili sebaran secara spasial dari wilayah kajian. Walaupun sampel kedalaman lapangan mewakili sebaran kedalaman, mungkin akan memberikan hasil yang lebih baik jika sebarannya mewakili seluruh wilayah kajian. Hal ini agar sifat perairan yang memberikan respon yang berbeda terhadap GEM dapat terwakili dari seluruh wilayah kajian.

Secara umum, kemampuan penetrasi GEM pada panjang gelombang lebih panjang, lebih rendah seiring bertambahnya kedalaman dibanding pada panjang gelombang lebih pendek, hal ini akan menghasilkan nilai rasio antara reflektansi pada band-band yang dirasiokan akan semakin meningkat seiring bertambahnya kedalaman. Hal menarik dari hasil regresi rasio band terhadap data lapangan adalah nilai rasio band berbanding terbalik dengan kedalaman lapangan. Hal ini menunjukkan bahwa besarnya reflektansi pada masing-masing band di lokasi kajian berdasarkan pertambahan kedalaman tidak memberikan pola yang teratur seiring bertambahnya kedalaman. Berbeda dengan hasil regresi yang dilakukan oleh Loomis (2009) pada rasio band citra Quickbird yang menunjukkan perbandingan lurus dengan sampel data kedalaman lapangan. Hal ini disebabkan oleh perbedaan jumlah dan jenis material dalam kolom air, serta jenis substrat yang dominan pada dasar perairan sehingga memberikan respon yang berbeda-beda pada setiap panjang gelombang.

Pada gambar 3 disajikan pola reflektansi pada 4 band yang digunakan dalam kajian ini berdasarkan garis sampling yang diambil tegak lurus ke arah perairan yang lebih dalam (a ke b). Pada gambar $3 \mathrm{~b}$ terlihat reflektansi band 2 dan band 3 pada perairan yang lebih dangkal memiliki nilai yang lebih tinggi dari band 1 dan band 4 . Band 1 dan band 4 lebih banyak terserap pada wilayah dangkal, substrat pasir yang dominan menutupi dasar perairan yang lebih dangkal menghasilkan nilai reflektasni yang lebih besar pada band 2 dan band 3. Akan tetapi band 1 mengalamai penyerapan yang lebih lambat dengan bertambahnya kedalaman. Hal ini terlihat dari pola nilai reflektansi pada 4 band (Gambar 3b) dimana pada band 2 dan 3 cenderung lebih cepat menurun dibandingkan pada band 1 . Kemampuan GEM pada panjang gelombang lebih pendek untuk melakukan penetrasi pada kolom air yang lebih dalam adalah alasan mengapa reflektansi pada band 1 di wilayah kajian ini cenderung lebih lambat menurun seiring bertambahnya kedalaman dibandingkan band 2 dan band 3 .

Gambar 3. Pola reflektansi spektral 4 band dari daerah dangkal ke daerah lebih dalam

(Analisis, 2014)

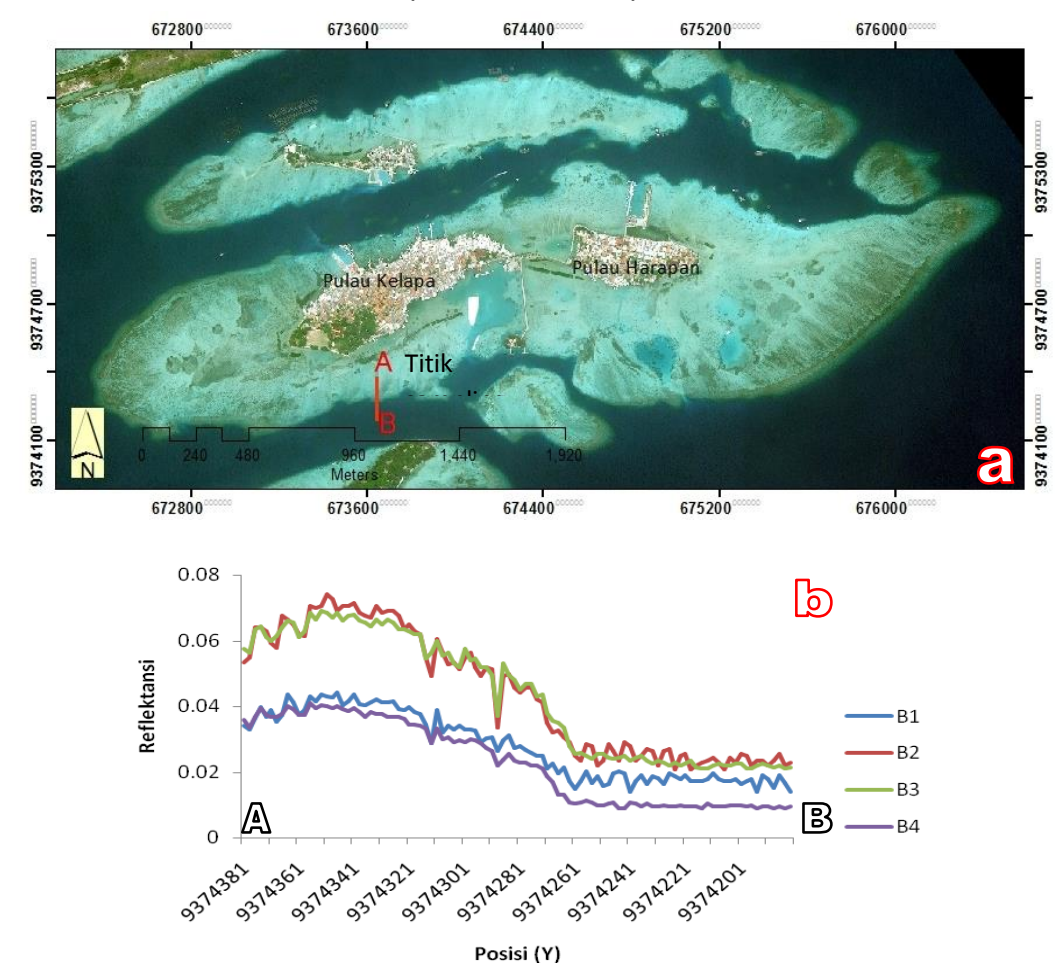




\subsection{Akurasi Hasil Estimasi}

Merujuk pada nilai $\mathrm{R}^{2}$ dari hasil regresi yang dilakukan pada kombinasi band terhadap data lapangan, persamaan yang digunakan untuk mengkalibrasi hasil rasio band menjadi kedalaman estimasi adalah persamaan yang dihasilkan dari rasio band 1 dengan band 3 dan rasio antara band 1 dengan band 4. Untuk mengetahui besarnya bias yang terjadi antara kedalaman estimasi melalui citra dan kedalaman lapangan, dilakukan pengujian terhadap citra kedalaman. Sebanyak 40 titik sampel kedalaman lapangan digunakan untuk mengekstraksi nilai-nilai piksel pada citra WorldView-2 hasil transformasi kedalalaman. Selisih antara kedalaman duga dan kedalaman lapangan bervariasi mulai dari nilai terkecil 0,0029 $\mathrm{m}$ pada hasil transformasi menggunakan rasio band1/band3 dan 0,0059 $\mathrm{m}$ pada hasil transformasi band1/band4, sedangkan untuk selisih nilai tertinggi yaitu 4,687 m pada rasio band1/band3 dan $8,739 \mathrm{~m}$ pada hasil transformasi rasi band1/band4 (selengkapnya dapat dilihat pada tabel 1).

Tabel 1. Sampel kedalaman Lapangan dan kedalaman estimasi serta selisihnya (Analisis, 2014)

\begin{tabular}{|c|c|c|c|c|c|c|c|c|c|c|c|}
\hline \multirow[b]{2}{*}{ No } & \multicolumn{3}{|c|}{ Kedalaman (m) } & \multicolumn{2}{|c|}{$\operatorname{Bias}(\mathrm{m})$} & \multirow[b]{2}{*}{ No } & \multicolumn{3}{|c|}{ Kedalaman (m) } & \multicolumn{2}{|c|}{ Bias (m) } \\
\hline & Lap. & B1/B3 & B1/B4 & B1/B3 & B1/B4 & & Lap. & B1/B3 & B1/B4 & B1/B3 & B1/B4 \\
\hline 1 & 1.6 & 1.4347 & 1.5406 & 0.16534 & 0.05938 & 21 & 6.5 & 5.6924 & 8.761 & 0.80756 & 2.26098 \\
\hline 2 & 2 & 2.0029 & 4.8363 & 0.00292 & 2.83632 & 22 & 7 & 5.0817 & 7.7539 & 1.91832 & 0.75391 \\
\hline 3 & 2.1 & 2.5381 & 2.5967 & 0.43813 & 0.49671 & 23 & 7.1 & 5.0817 & 7.7539 & 2.01832 & 0.65391 \\
\hline 4 & 2.2 & 2.0029 & 4.8363 & 0.19708 & 2.63632 & 24 & 7.2 & 7.7748 & 11.345 & 0.57475 & 4.1447 \\
\hline 5 & 2.3 & 2.5381 & 2.5967 & 0.23813 & 0.29671 & 25 & 7.3 & 6.1806 & 0.8287 & 1.11944 & 6.47131 \\
\hline 6 & 2.5 & 2.5381 & 2.5967 & 0.03813 & 0.09671 & 26 & 7.4 & 7.1024 & 7.5516 & 0.29765 & 0.15159 \\
\hline 7 & 2.6 & 1.9118 & 0.6947 & 0.68821 & 1.90534 & 27 & 7.5 & 7.8854 & 11.218 & 0.38542 & 3.7183 \\
\hline 8 & 3.1 & 3.2516 & 1.4135 & 0.15155 & 1.68655 & 28 & 8 & 7.2472 & 10.59 & 0.7528 & 2.5896 \\
\hline 9 & 3.4 & 1.8982 & 5.345 & 1.50181 & 1.94502 & 29 & 9 & 8.7126 & 11.804 & 0.28739 & 2.8037 \\
\hline 10 & 3.7 & 3.303 & 8.3949 & 0.39698 & 4.69488 & 30 & 10.6 & 5.913 & 9.6581 & 4.68697 & 0.94189 \\
\hline 11 & 3.8 & 3.0967 & 2.1476 & 0.70326 & 1.65241 & 31 & 11.3 & 11.2 & 10.542 & 0.1003 & 0.7578 \\
\hline 12 & 4.1 & 4.8103 & 4.3482 & 0.71026 & 0.24815 & 32 & 13.6 & 13.52 & 12.128 & 0.08 & 1.4717 \\
\hline 13 & 4.2 & 5.6924 & 8.761 & 1.49244 & 4.56098 & 33 & 14 & 11.369 & 10.221 & 2.631 & 3.7788 \\
\hline 14 & 4.6 & 5.3632 & 6.1943 & 0.76317 & 1.59432 & 34 & 14.8 & 16.203 & 12.947 & 1.4029 & 1.8534 \\
\hline 15 & 4.7 & 4.771 & 7.07 & 0.07095 & 2.36998 & 35 & 16.8 & 16.892 & 17.628 & 0.092 & 0.8284 \\
\hline 16 & 5.1 & 5.6924 & 8.761 & 0.59244 & 3.66098 & 36 & 18.6 & 15.042 & 14.986 & 3.5583 & 3.6137 \\
\hline 17 & 5.2 & 4.8817 & 11.991 & 0.3183 & 6.7913 & 37 & 19.5 & 16.066 & 12.268 & 3.4339 & 7.232 \\
\hline 18 & 5.7 & 7.4429 & 6.886 & 1.74286 & 1.18601 & 38 & 20.4 & 17.559 & 18.131 & 2.8409 & 2.2693 \\
\hline 19 & 6 & 8.1734 & 9.1973 & 2.1734 & 3.19734 & 39 & 22.8 & 19.311 & 15.715 & 3.4889 & 7.0855 \\
\hline \multirow[t]{2}{*}{20} & 6.4 & 6.8334 & 9.5211 & 0.43339 & 3.12113 & 40 & 23.2 & 19.592 & 14.46 & 3.6082 & 8.7398 \\
\hline & & & & & & & \multicolumn{3}{|c|}{ Rata-Rata Bias (m) } & 0.64094 & 2.25183 \\
\hline
\end{tabular}

Dari tabel 1 terlihat rata-rata bias (selisih) antara kedalaman hasil transformasi citra dan kedalaman lapangan untuk rasio band1/band3 cukup kecil yaitu hanya 0,6049 $\mathrm{m}$, dan bias yang banyak terjadi yaitu pada kedalaman diatas $13 \mathrm{~m}$. Hal ini menunjukkan bahwa kombinasi band 1/band3 pada perairan ini cukup baik digunakan hanya untuk kedalaman dibawah $13 \mathrm{~m}$. Pada gambar $3 \mathrm{~b}$ terlihat bahwa pola reflektansi dari band 1 dan band 3 cukup kontras pada perairan yang lebih dangkal, namun cenderung memiliki nilai reflektansi hampir sama pada perairan yang lebih dalam. Band 1 (Coastal) pada citra WorldView 2 berada pada rentang panjang gelombang yang lebih pendek sehingga diharapkan memiliki kemampuan penetrasi kedalaman yang lebih besar dari band-band lainnya (DigitalGlobe 2010). Pada kajian ini terlihat bahwa band 1 justru memiliki nilai reflektansi yang lebih rendah dari band 2 dan band 3 baik pada perairan dangkal maupun perairan yang lebih dalam, akan 
tetapi nilai reflektansi band 2 dan band 3 cenderung lebih cepat menurun seiring bertambahnya kedalaman (Gambar 3b). Substrat pasir yang dominan pada perairan dangkal diduga menjadi faktor yang sangat berpengaruh pada reflektansi dari kolom air sehingga memberikan nilai yang lebih tinggi pada band 2 dan band 3 pada perairan yang lebih dangkal.

Sifat respon spektral yang berbeda pada jenis substrat yang berbeda diduga menjadi penyebab utama rendahnya korelasi antara rasio band terhadap kedalaman lapangan sehingga menyebabkan besarnya bias antara kedalaman duga dan kedalaman lapangan pada kajian ini. Dasar perairan yang didominasi oleh pasir akan memberikan nilai reflektansi yang lebih besar dari dasar perairan yang banyak terdapat karang dan lamun. Algoritma rasio band memanfaatkan kombinasi 2 buah band yang berbeda dengan harapan akan memberikan hasil estimasi kedalaman yang lebih akurat hingga pada perairan yang memiliki beragam jenis substrat (Stumpf et al 2003), asumsi ini dibangun berdasarkan sifat respon spektral yang berbeda pada masing-masing band berdasarkan jenis substrat dasar. Sehingga dengan memanfaatkan rasio band, diharapkan akan mewakili variasi respon spektral pada masing-masing tipe substrat dasar. Loomis (2009) mampu meningkatkan akurasi hasil pendugaan kedalaman perairan menggunakan algoritma rasio band berdasarkan pemisahan tipe substrat dasar perairan. Kajian yang dilakukan olah Siregar dan Selamat (2010) dalam mengevaluasi citra Quickbird untuk memetakan batimetri pada gobah Karang Lebar dan Pulau Panggang menggunakan algoritma berdasarkan Zona Penetrasi Kedalaman (ZPK) menemukan bahwa algoritma tersebut tidak konsisten memberikan hasil pendugaan yang akurat pada wilayah kajian. Adanya perbedaan kualitas dan tipe perairan menjadi penyebab ketidak konsistenan algoritma tersebut.

Penyebab lain besarnya bias dan rendahnya korelasi antara rasio band pada citra WorldView-2 terhadap kedalaman lapangan yaitu diduga adanya distorsi dari GPS pada perangkat sounding yang digunakan di lapangan. Tingginya resolusi spasial pada citra WorldView-2 menjadikan beragamnya informasi yang terdapat pada suatu luasan sempit berdasarkan nilai reflektansi pada masing-masing piksel pada luasan tersebut. Untuk meningkatkan akurasi pendugaan kedalaman, diperlukan proses lebih lanjut untuk mencocokkan posisi antara GPS yang digunakan pada suatu titik di lapangan terhadap piksel yang mewakili titik tersebut. Pada gambar 4 terlihat daerah yang banyak terdapat bias dalam estimasi kedalaman pada citra yaitu pada bagian Selatan perairan, baik pada rasio band 1 dan band 3 maupun band 1 dan band 4 . Hal ini kemungkinan disebabkan kurangnya sampel data kedalaman lapangan yang diambil mewakili wilayah ini pada saat melakukan regresi terhadap hasil rasio band.

Gambar 4. Citra kedalaman perairan lokasi studi, a) Hasil transformasi rasio band1/band 3; dan b) hasil transformasi rasio band 1/band 4 (Analisis, 2014)

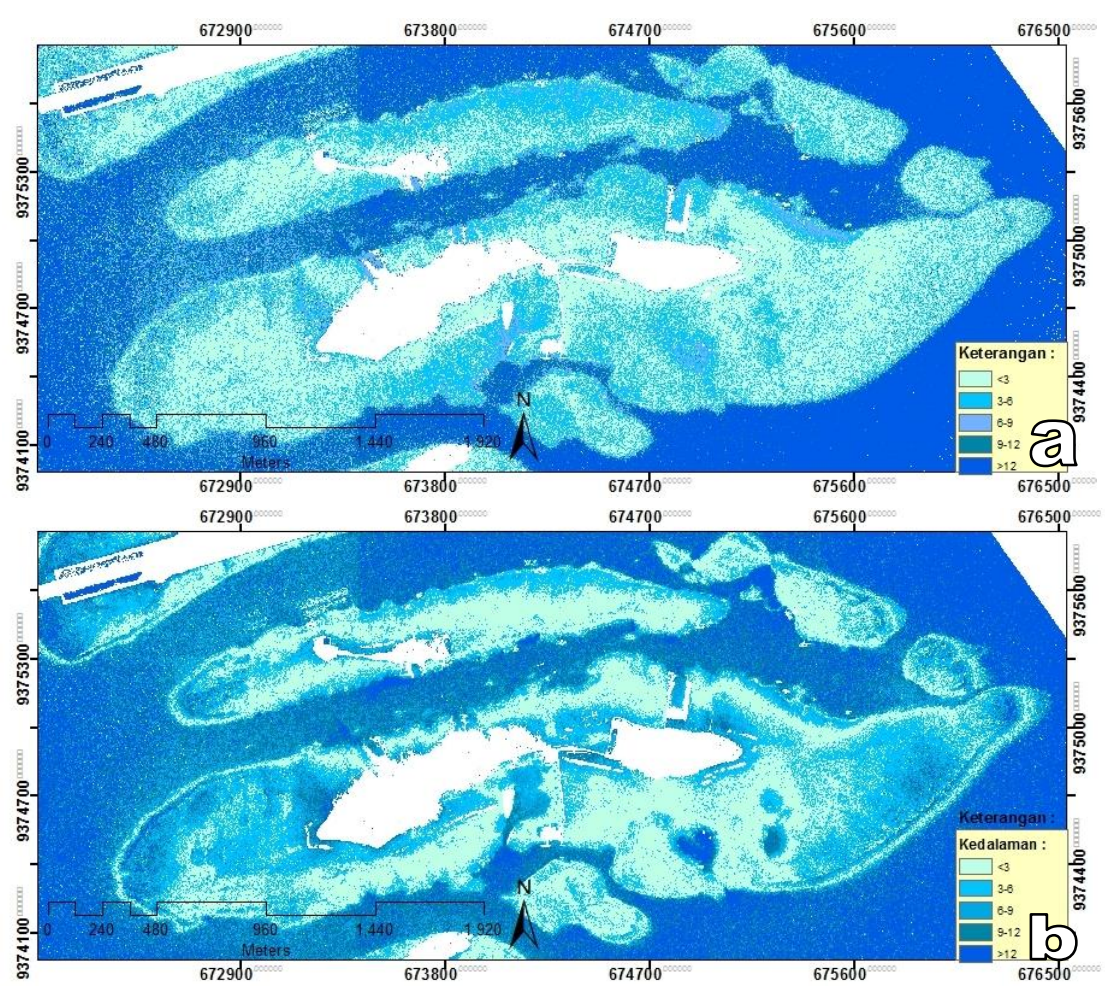




\section{KESIMPULAN}

Beberapa hal yang dapat disimpulkan berdasarkan hasil penelitian ini yaitu, 1) Dari 6 kombinasi band yang digunakan untuk mengestimasi kedalaman pada perairan dangkal Pulau Kelapa-Harapan, kombinasi band terbaik dengan nilai rata-rata error terkecil adalah rasio antara band 1 dan band 3. 2) Kedalaman maksimum yang dapat diestimasi dengan baik dari citra WorldView-2 menggunakan algoritma rasio band adalah $13 \mathrm{~m}$. 3) Selisih antara kedalaman duga dan kedalaman lapangan kemungkinan dapat diperkecil dengan memisahkan proses estimasi kedalaman berdasarkan jenis substrat dasar.

\section{DAFTAR PUSTAKA}

Digital Globe. (2010). Radiometric use of WorldView-2 imagery. Technical note. Prepared by : Todd Updike, Chris Comp.

Doxani G, Papadopulou M, Lafaxani P, Tsakiri-Strati M. (2012). Shallow-water bathymetry over variable bottom types using multispectral worldview-2 image. International Archives of the Photogrammetry, Remote Sensing and Spatial Information Sciences, 39(8).

Friedlander AM., Brown EK., and Monaco ME. (2007). Coupling ecology and GIS to evaluate efficacy of marine protected areas in Hawaii. Ecological Applications, 17(3):715-730.

Kay S., Hedley JD. and Lavender S. (2009). Sun glint correction of high and low spatial resolution images of aquatec scenes : a review of method for visible and near-infrared wavelengths. Remote Sens, 1:697730.

Kuffner IB., Brock JC., Grober-Dunsmore R., Bonito BE., Hickey TD., and Wright CW. (2007). Relationship between reef fish communities and remotely sensed rugosity measurements in Biscayne National Park, Florida, USA. Environ Biol Fish, Vol. 78:71-78.

Loomis MJ. (2009). Depth derivation from the WorldView-2 satellite using hyperspectral imagery. Naval Postgraduate School.

Madden CK. Contributions to remote sensing of shallow water depth with the Worldview-2 yellow band. Naval Postgraduate School.

Siregar VP, Selamat MB. (2010). Evaluasi citra quickbird untuk pemetaan batimetri gobah dengan menggunakan data perum: studi kasus gobah Karang Lebar dan Pulau Panggang. Ilmu Kelautan, UNDIP

Stumpf RP, Holderied K, and Sinclair M. (2003). Determination of water depth with high-resolution satellite imagery over variable bottom types. Applied Optics, Vol. 28(8):547-556.

Susilo SB. (2007). Analisis keberlanjutan pembangunan pulau-pulau kecil: pendekatan model ekologiekonomi. Jurnal Ilmu-IImu Perairan dan Perikanan Indonesia, Vol. 14(1):29-35. 